\title{
Terminal Ileitis: A Rare Complication of Henoch-Schönlein Purpura in Children
}

\section{Ileíte Terminal: Uma Complicação Rara da Púrpura de Henoch- Schonlein na Criança}

Ana Lia Costa Mano ${ }^{1}$, Mafalda Casinhas Santos ${ }^{2 *}$, Sara Limão², Florbela Cunha²

\section{ABSTRACT}

Henoch-Schönlein purpura (HSP) is characterized by nonthrombocytopenic palpable purpura, arthritis or arthralgia, and gastrointestinal and/or renal involvement. Gastrointestinal symptoms are reported in 50\%-75\% and they are related to a previous group A streptococcal infection in $40 \%$.

A healthy 5-year-old girl presented with a three-week history of a recurrent purpuric rash on the lower limbs, arthralgia and angioedema, without renal involvement. During the third relapse, she had severe, diffuse and persistent abdominal pain and bloody stools. An abdominal ultrasound revealed transmural edema of the last ileal segment, compatible with ileitis. She received prednisolone for five days, with full clinical recovery. Antistreptolysin O titer was elevated. The remaining laboratory tests were normal (antinuclear, anti-neutrophil and anti-Saccharomyces cerevisiae antibodies; rheumatoid factor; stool cultures, parasitological examination and viral antigen tests). One month later, an abdominal ultrasound revealed no abnormalities. Terminal ileitis is a very rare complication of HSP in children but has a good prognosis.

KEYWORDS: Child; Ileitis; Purpura, Schoenlein-Henoch 


\section{RESUMO}

A púrpura de Henoch-Schonlein (PHS) é caracterizada por púrpura palpável não trombocitopénica, artrite ou artralgia e envolvimento renal e/ou gastrointestinal. Os sintomas gastrointestinais ocorrem em 50\%-75\% dos casos e estão relacionados com infeção prévia a streptococus grupo A em 40\%. Uma rapariga saudável com 5 anos de idade apresentou-se com história com 3 semanas de evolução de rash purpúrico recidivante nos membros inferiores, artralgia e angioedema, sem envolvimento renal. Durante a terceira recidiva, apresentou dor abdominal intensa, difusa e persistente e dejeções com sangue. A ecografia abdominal revelou edema transmural do último segmento ileal, compatível com ileíte. Cumpriu prednisolona por 5 dias, com recuperação clínica completa. $O$ título anti-estreptolisina $\mathrm{O}$ estava elevado. A restante avaliação laboratorial era normal (anticorpos antinuclear, anti-neutrófilos e anti-Saccharomyces cerevisiae, fator reumatoide, cultura das fezes e exame parasitológico e teste de antigénio viral). Um mês depois, a ecografia abdominal não revelou alterações. A ileíte terminal é uma complicação rara da PHS, mas apresenta um bom prognóstico.

PALAVRAS-CHAVE: Criança; Ileíte; Púrpura Henoch-Schonlein

\section{INTRODUCTION}

Henoch-Schönlein purpura (HSP) is a leukocytoclastic vasculitis characterized by a classic tetrad of nonthrombocytopenic purpura, arthritis or arthralgia, gastrointestinal and renal involvement. It mostly affects children, of which $90 \%$ are less than ten years of age. ${ }^{1}$ Although its etiopathogenesis is still unknown, a previous group A streptococcal (GAS) infection, is related to $40 \%$ of the cases. ${ }^{2}$ Other risk factors have been implicated, such as vaccinations, some foods and insect stings. ${ }^{3,4}$ Although recurrence rate is variable among children (2.7\% to $30.0 \%),{ }^{5}$ HSP is self-limited in the great majority of cases. ${ }^{6,7}$ Age at onset above eight years-old is related to greater disease severity, renal involvement and recurrence. ${ }^{8,9}$

The rash usually begins as erythematous, macular or urticarial wheals and evolves to a palpable purpura. It typically appears in crops with a symmetrical distribution in gravity-dependent areas, mainly the lower limbs and buttocks. It is usually itchy and rarely painful. Localized angioedema is commonly seen in gravity-dependent and periorbital locations. ${ }^{6}$

Gastrointestinal symptoms are observed in 50\%-75\% of the patients. ${ }^{10,11}$ The main clinical features are colicky abdominal pain, vomits and bleeding. ${ }^{1,11}$ Complications as intussusception, bowel ischemia, necrosis and perforation may occur. While the descending duodenum, stomach and colon are commonly involved, ${ }^{6}$ terminal ileitis has infrequently been recognized in HSP. ${ }^{1}$

Due to its rarity, we present a case of pediatric HSP complicated by terminal ileitis.

\section{CASE REPORT}

An otherwise healthy 5-year-old girl, with no relevant personal or familiar medical history, previous medication nor recent infections, presented with a two-week history of a recurrent purpuric and pruriginous rash on her lower extremities and painful and swollen soles of the feet, right hand and wrist. Fever, abdominal pain, hematochezia and melena were denied.

Physical examination revealed a healthy appearing girl and a palpable purpuric rash on the lower limbs and buttocks. Movements were restricted by significant arthralgia and prominent angioedema of feet, right hand and wrists. Abdominal examination was unremarkable. Blood pressure was normal for age, sex and height. C-reactive protein was raised $(8.82 \mathrm{mg} / \mathrm{dL} ; \mathrm{NR}<0.5$ $\mathrm{mg} / \mathrm{dL}$ ) and she presented leucocytosis $\left(25.3 \times 10^{3} / \mathrm{ML}\right)$ and neutrophilia $\left(14.90 \times 10^{3} / \mu \mathrm{L}\right)$. The remaining laboratory tests were normal: hemogram (hemoglobin $11.5 \mathrm{~g} / \mathrm{dL}$; Iymphocyte count $8.72 \times 10^{3} / \mathrm{ML}$; platelet count $452 \times 10^{3} / \mathrm{ML}$ ); prothrombin and partial thromboplastin time; liver function tests; blood urea nitrogen; serum creatinine; and ionogram. Urinalysis revealed no hematuria nor proteinuria. Rapid throat GAS test was negative. Serum concentrations of Immunoglobulin (Ig) A were slightly elevated (378 mg/dL; NR 40-141 mg/dL). IgM, IgE, C3, C4 and CH50 concentrations were normal. Antistreptolysin O (ASO) titer was positive $(531 \mathrm{lU} / \mathrm{mL}$; $\mathrm{NR}<200 \mathrm{IU} / \mathrm{mL}$ ). She was diagnosed with HSP and due to functional disability hospitalized for monitoring and symptomatic treatment. She was discharged after three days with clinical improvement. 

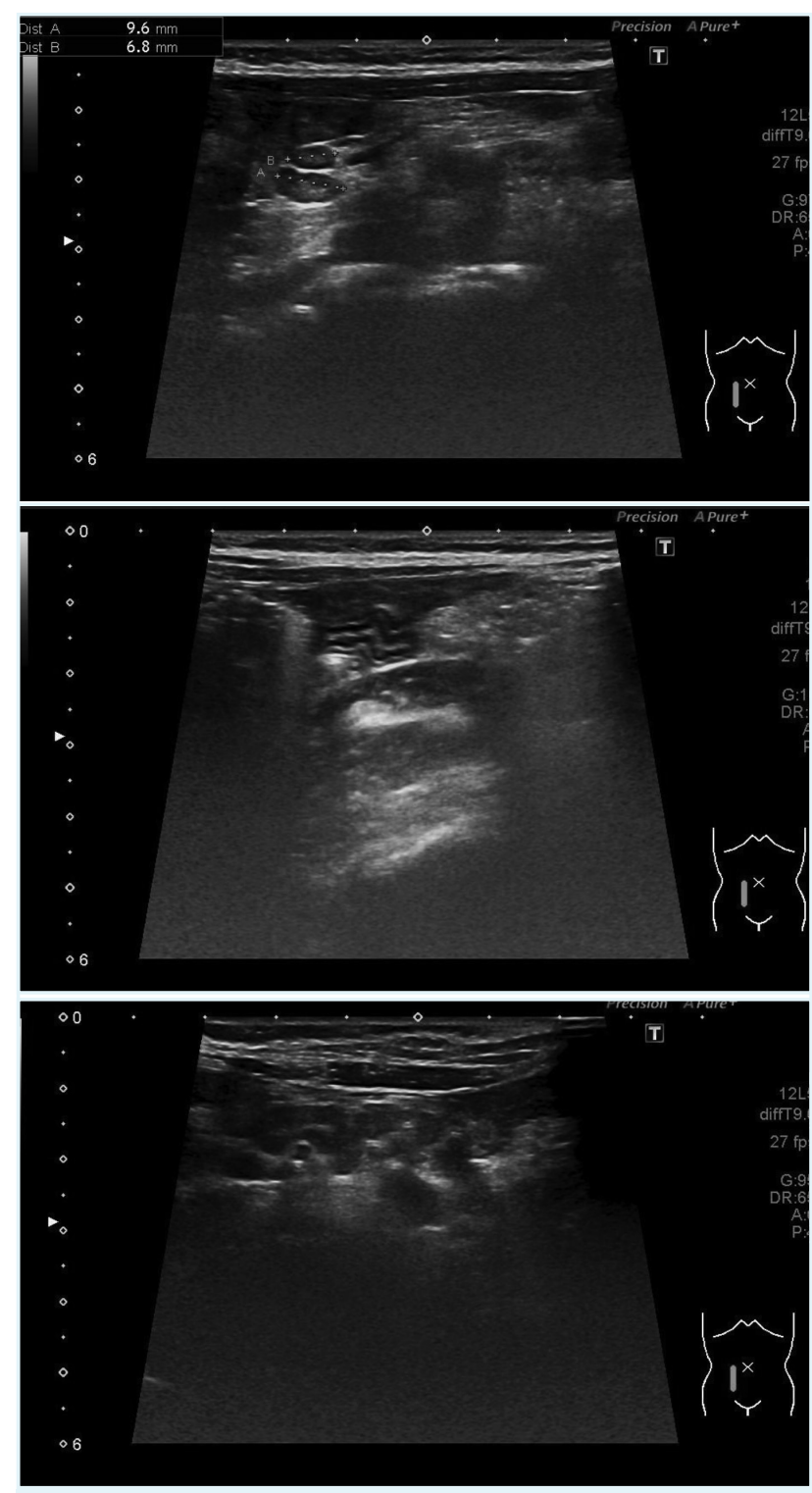

FIGURE 1. Abdominal ultrasound revealing signs of ileitis, with parietal, transmural edema of the last ileal segment ((A) and (B)), with small reactive ganglia on the mesenteric adipose tissue (C).

One week later, the patient was readmitted for rash recurrence and a new severe, diffuse and persistent abdominal pain. She reported stools with a small amount of bright red blood and mucus. She denied rectal pain, diarrhea or visible blood on toilet paper. The abdomen was diffusely tender without signs of peritoneal irritation nor palpable masses. Digital rectal examination was normal. Laboratory findings were similar to those previously reported. An abdominal ultrasound revealed "signs of ileitis, with transmural parietal edema of the last ileal segment and small reactive ganglia on the mesenteric adipose tissue" (Fig. 1). The patient received prednisolone (2 mg/kg/day) for five days, with full clinical recovery.

Tests for antinuclear antibodies, rheumatoid factor, antineutrophil cytoplasmic antibodies (ANCA) and anti-Saccharomyces cerevisiae antibodies (ASCA), as well as stool cultures, parasitological examination and viral antigen tests (including Yersinia, Campylobacter, Shigella and Salmonella) were negative. B19 Parvovirus serology was not compatible with an acute infection.

One month after hospital discharge, an abdominal ultrasound revealed no abnormalities.

\section{DIFFERENTIAL DIAGNOSIS}

HSP accompanied by terminal ileitis should prompt consideration to a broad differential diagnosis and investigation, including Crohn's disease, vasculitic syndromes, infections, ${ }^{1}$ appendicitis and, especially, intussusception. ${ }^{12,13}$

Abdominal findings were not compatible with emergent conditions, such as appendicitis or intussusception.

The typical HSP rash along with normal levels of serum complement, antinuclear antibodies and rheumatoid factor did not suggest an autoimmune vasculitic disease, like systemic lupus erythematosus or juvenile idiopathic arthritis.

Terminal ileitis has been associated with Yersinia, Campylobacter and Salmonella infections. ${ }^{13}$ Adenovirus is typically not related, though it has been reported to cause intussusception..$^{13}$ Negative stool cultures, parasitological and viral tests ruled out these causes.

Terminal ileitis may be caused by Crohn's disease, ${ }^{1}$ but this correlation is rare in children. ${ }^{13}$ Our patient's age is not typical at Crohn's disease onset. In addition, hematochezia was concomitant with abdominal pain, which suggests HSP. Furthermore, ANCA and ASCA tests were negative and follow-up abdominal ultrasound was normal. However, a negative serologic tests does not exclude Crohn's disease, ${ }^{14}$ which should be suspected if persistent gastrointestinal symptoms are present. $^{11}$

\section{OUTCOME AND FOLLOW-UP}

Three months later the patient HSP had a new relapse with no abdominal complaints, following a GAS tonsillitis (rapid throat GAS test positive) treated with intramuscular 1200000 IU of benzathine penicillin.

During the next 24-month follow-up period, there was no clinical relapse, nor gastrointestinal symptoms or signs of renal involvement.

\section{DISCUSSION}

Gastrointestinal symptoms occur in approximately onehalf of children with HSP, ranging from mild (nausea, vomiting and abdominal pain) to significant complications, namely hemorrhage, bowel ischemia and necrosis, 
intussusception, and bowel perforation. ${ }^{6}$ Intussusception is the most frequent gastrointestinal complication. Less common manifestations include acute pancreatitis, gall bladder involvement, bowel perforation, and, in pediatric patients, protein-losing enteropathy. ${ }^{6}$ Terminal ileitis is very rare and, to date, has been reported in thirteen adults of whom four pediatric patients. ${ }^{15}$ Gastrointestinal symptoms usually begin two weeks after the rash development, however, longer periods ranging from weeks to months have been reported. ${ }^{9}$ In approximately $15 \%$ to $35 \%$ of the cases, these symptoms may precede the rash, making the diagnosis more difficult. Gastrointestinal complaints without the presence of purpura at any time has also been reported. ${ }^{16,17}$

Terminal ileitis was the first manifestation of HSP in previously reported pediatric cases. ${ }^{1}$ Our patient revealed terminal ileitis and gastrointestinal symptoms along with skin and articular involvement by the third week of recurrence. The reason behind the single involvement of the ileum remains obscure. Hyperactivation of IgA laden Peyer's plaques by multiple antigenic stimuli, including enteric pathogens, has been suggested as a trigger for ileal inflammation. IgA induction would subsequently spread to other organs due to antigenic mimicry. ${ }^{18}$ In the present case, the last relapse was triggered by a GAS tonsillitis and there was evidence of a high ASO titer. These facts strongly suggest correlation with a triggering streptococcal infection. No enteric pathogens were found. Identification of an infectious cause is infrequent. ${ }^{13}$

Streptococcal infections may be an important factor related to HSP in children. In fact, purpura with abdominal pain recurrence has been related to GAS infection, which is of great value to treatment. ${ }^{19}$ Although there is an association between a positive ASO titer and HSP, it does not necessarily reflect a causal relationship. GAS infection may be a factor among multiple changes that lead to the development of HSP in a susceptible individual, whether genetically or not. Also, specific bacteria strains may have a variable influence on this association. $^{20}$

Ultrasonography may be an important tool before expensive and invasive tests are considered, ${ }^{21}$ especially when intussusception or bowel perforation are suspected. ${ }^{6}$ Bowel wall thickness evolution and other sonographic abnormalities have a good correlation with clinical outcome. Routine abdominal radiographs are not recommended, unless perforation is clinically suspected. ${ }^{21}$ An ultrasonography allowed the diagnosis and follow-up of terminal ileitis in our patient, as well as the exclusion of other complications.
No large-scale studies are available and there is no consensus regarding the use of corticotherapy for the management of HSP. ${ }^{22}$ Some reports suggest that it may improve abdominal pain, ${ }^{23}$ but does not prevent recurrence. ${ }^{21}$ In a study involving 30 adults and 57 children with HSP, steroids were prescribed mainly because of persistent skin lesions, severe abdominal pain, gastrointestinal bleeding or severe nephropathy. ${ }^{23}$ Our patient only took corticosteroids for a short period, when abdominal pain developed, with a good clinical evolution.

This case describes a recurrent HSP probably related to a GAS infection, without renal involvement, developing terminal ileitis, a rare gastrointestinal complication with a good prognosis.

\section{LEARNING POINTS/TAKE HOME MESSAGES}

- Although HSP is self-limited and with a good prognosis in the great majority of cases, recurrence is common among children.

- GAS is associated with HSP recurrence, which is of great value to treatment.

- Terminal ileitis may be a rare gastrointestinal complication of HSP without long-term sequelae.

- Ultrasound is very helpful in the diagnosis of abdominal manifestations.

\section{RESPONSABILIDADES ÉTICAS}

CONFLITOS DE INTERESSE: Os autores declaram a inexistência de conflitos de interesse na realização do presente trabalho.

FONTES DE FINANCIAMENTO: Não existiram fontes externas de financiamento para a realização deste artigo.

CONFIDENCIALIDADE DOS DADOS: Os autores declaram ter seguido os protocolos da sua instituição acerca da publicação dos dados de doentes.

CONSENTIMENTO: Consentimento do doente para publicação obtido.

PROVENIÊNCIA E REVISÃO POR PARES: Não comissionado; revisão externa por pares.

\section{ETHICAL DISCLOSURES}

CONFLICTS OF INTEREST: The authors have no conflicts of interest to declare. 
FINANCING SUPPORT: This work has not received any contribution, grant or scholarship.

CONFIDENTIALITY OF DATA: The authors declare that they have followed the protocols of their work center on the publication of data from patients.

PATIENT CONSENT: Consent for publication was obtained.

PROVENANCE AND PEER REVIEW: Not commissioned; externally peer reviewed.

\section{REFERENCES}

1. Kanik A, Kose E, Baran M, Kose SS, Eliacik K, Sayan A, et al. Henoch-Schönlein purpura in two pediatric patients presenting as terminal ileitis. Dig Dis Sci. 2015;60:269-71. doi: 10.1007/ s10620-014-3273-5.

2. Arslansoyu Çamlar S, Soylu A, Akil L, Akil i, Ünlü M, Coşkun Ş, et al. Henoch-Schönlein purpura, post-streptococcal glomerulonephritis and acute rheumatic carditis after Group A $\beta$-haemolytic streptococcal infection. Paediatr Int Child Health. 2018;38:73-5. doi: 10.1080/20469047.2017.1284394.

3. Dillon MJ. Childhood vasculitis. Lupus. 1998;7:259-65.

4. Ebert EC. Gastrointestinal manifestations of Henoch-Schönlein Purpura. Dig Dis Sci. 2008;53:2011-9.

5. Wei-Te Lei, Tsai PL, Chu SH, Kao YH, Lin CY, Fang LC, et al. Incidence and risk factors for recurrent Henoch-Schönlein purpura in children from a 16-year nationwide database. Pediatr Rheumatol Online J. 2018;16:25. doi: 10.1186/s12969-0180247-8.

6. Dedeoglu F, Kim S. IgA vasculitis (Henoch-Schönlein purpura): Clinical manifestations and diagnosis. UpToDate. 2019 [accessed Jan 2021] Available from: https://www.uptodate. com/contents/iga-vasculitis-henoch-schonlein-purpura-clinical-manifestations-and-diagnosis (Acessed on March 2020).

7. Shim JO, Han K, Park S, Kim GH, Ko JS, Chung JY. Ten-year Nationwide Population-based Survey on the Characteristics of Children with Henoch-Schönlein Purpura in Korea. J Korean Med Sci. 2018;33:e174. doi: 10.3346/jkms.2018.33.e174.

8. Jauhola $\bigcirc$, Ronkainen J, Koskimies $\mathrm{O}$, Ala-Houhala M, Arikosk P, Hölttä T, et al. Clinical course of extrarenal symptoms in Henoch-Schönlein purpura: a 6-month prospective study. Arch Dis Child. 2010;95:871-6. doi: 10.1136/adc.2009.167874.

9. Sampat HN, McAllister BP, Gaines DD, Ostrov B. Terminal Ileitis as a Feature of Henoch-Schönlein Purpura Masquerading as Crohn Disease in Adults. J Clin Rheumatol. 2016;22:82-5.

10. Rubino C, Paci M, Resti M, Lionetti P, Trapani S. Late Relapse of Henoch-Schönlein Purpura in an Adolescent Presenting as Severe Gastroduodenitis. Front Pediatr. 2018;6:355. doi: 10.3389/fped.2018.00355.

11. Saulsbury FT, Hart MH. Crohn's Disease Presenting with Henoch-Schönlein Purpura. J Pediatr Gastroenterol Nutr. 2000;31:173-5.

12. Fan Z, Tian X, Pan J, Li Y, Zhang $Y$, Jing $H$. Terminal ileitis induced by Henoch-Schönlein purpura that presented as acute appendicitis: a case report. Medicine. 2015;94:e492. doi: 10.1097/MD.0000000000000492.

13. Gutiérrez MMA, Martínez-Ojinaga NE, Díez PJ, et al. Acute Terminal Ileitis in Children: A Retrospective Study in Pediatric Emergency Department. Pediatr Emerg Care. 2019;35:24951.
14. Reese GE, Constantinides VA, Simillis C, et al. Diagnostic Precision of Anti-Saccharomyces cerevisiae Antibodies and Perinuclear Antineutrophil Cytoplasmic Antibodies in Inflammatory Bowel Disease. Am J Gastroenterol. 2006;101:2410-22.

15. Sampat HN, McAllister BP, Gaines DD, Ostrov B. Terminal ileitis as a feature of henoch-schönlein purpura masquerading as Crohn disease in adults. J Clin Rheumatol. 2016;22:82-5. doi:10.1097/RHU.0000000000000361.

16. Feldt RH, Stickler GB. The gastrointestinal manifestations of anaphylactoid purpura in children. Proc Staff Meet Mayo Clin. 1962;37:465-73.

17. Nathan K, Gunasekaran TS, Berman JH. Recurrent gastrointestinal Henoch-Schönlein purpura. J Clin Gastroenterol. 1999;29:86-9.

18. Gunasekaran TS, Berman J, Gonzalez M. Duodenojejunitis: is it idiopathic or is it Henoch-Schönlein purpura without the purpura? J Pediatr Gastroenterol Nutr. 2000;30:22-8.

19. Fagarasan S, Honjo T. Regulation of IgA synthesis at mucosal surfaces. Curr Opin Immunol. 2004;16:277-83.

20. Li F, Zeng H. AB0560 Study on streptococcal infection relationship with henoch-schönlein purpura in children. Ann Rheum Dis. 2020;76:1246.

21. Al-Sheyyab M, Batieha, A, El-Shanti H, Daoud, A. Henoch-Schönlein purpura and streptococcal infection: a prospective case-control study. Ann Trop Pediatr. 1999;19:253-5.

22. Haroon M. Should children with Henoch-Schönlein purpura and abdominal pain be treated with steroids? Arch Dis Child. 2005;90:1196-8.

23. Gupta V, Aggarwal A, Gupta R, Chandra Chowdhury A, Agarwal $\vee$, Lawrence A, et al. Differences between adult and pediatric onset Henoch-Schönlein purpura from North India. Int J Rheum Dis. 2018;21:292-8. doi: 10.1111/1756-185X.13221. 